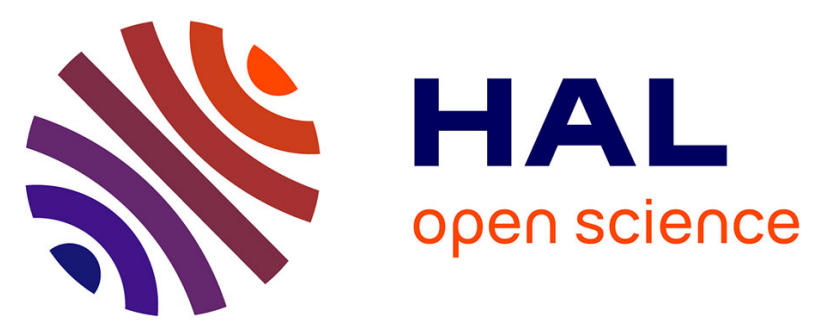

\title{
The Ban Don Mun artifacts: A chronological reappraisal of human occupations in the Lampang province of Northern Thailand
}

\author{
Valery Zeitoun, Hubert Forestier, Michel Rasse, Prasit Auetrakulvit, \\ Jeongmin Kim, Chaturaporn Tiamtinkrit
}

\section{To cite this version:}

Valery Zeitoun, Hubert Forestier, Michel Rasse, Prasit Auetrakulvit, Jeongmin Kim, et al.. The Ban Don Mun artifacts: A chronological reappraisal of human occupations in the Lampang province of Northern Thailand. Journal of Human Evolution, 2013, 65 (1), pp.10-20. 10.1016/j.jhevol.2013.02.013 . hal-02977030

\section{HAL Id: hal-02977030 \\ https: / hal.sorbonne-universite.fr/hal-02977030}

Submitted on 23 Oct 2020

HAL is a multi-disciplinary open access archive for the deposit and dissemination of scientific research documents, whether they are published or not. The documents may come from teaching and research institutions in France or abroad, or from public or private research centers.
L'archive ouverte pluridisciplinaire HAL, est destinée au dépôt et à la diffusion de documents scientifiques de niveau recherche, publiés ou non, émanant des établissements d'enseignement et de recherche français ou étrangers, des laboratoires publics ou privés. 
THE BAN DON MUN ARTIFACTS: A CHRONOLOGICAL REAPRAISAL OF HUMAN OCCUPATIONS IN THE LAMPANG PROVINCE OF NORTHERN THAILAND.

\author{
Valery Zeitoun \\ 252 Paris Cedex 05, France. \\ Hubert Forestier \\ UMR 7194 CNRS-Mnhn, 1 rue René Panhard, 75013 Paris, France.
}

UMR 7207, CNRS-Mnhn-Upmc, Centre de Recherche sur la Paléobiodiversité et les Paléoenvironnements, Université Pierre et Marie Curie, T. 46-56, 5ème étage, case 104, 4, place Jussieu, 75

\title{
Michel Rasse
}

Department of Geography, University of Rouen, 76821 Mont Saint-Aignan cedex, France.

\section{Prasit Auetrakulvit}

Department of Archaeology, Faculty of Archaeology, Silpakorn University, Na Phra road, 10220 Bangkok, Thailand.

\section{Jeongmin Kim}

Division of Earth and Environmental Sciences, Korea Basic Science Institute, Ochang Centre, Chungbuk 363-883, South Korea.

\section{Chaturaporn Tiamtinkrit}

$6^{\text {th }}$ Archaeological Division of Fine Arts Department, Nan Museum, Thailand.

\begin{abstract}
India, the timing and geography of human demographic expansions in continental Southeast Asia remains ambiguous. The recent discovery of a series of stone artifacts spread over a basalt level at Ban Don Mun in the Lampang province of northern Thailand presents an ideal opportunity for reevaluating lithic assemblages documented during the 1970s and 1980s in the same region. Both the position of these stone tools and new absolute dates indicate a Middle Pleistocene age and call into question the status of these artifacts as the oldest yet found in Southeast Asia. The uncertain geo-chronological context and technological analysis of the chopper industry from previous work in the Lampang area prompted us to undertake new surveys in continental Southeast Asia in order to help clarify the route and timing of Pleistocene human expansions in this part of the world.
\end{abstract}

Keywords: Southeast Asia, Middle Pleistocene, chopper, chronology, Movius Line.

\section{Introduction}

East Asian prehistory as a discipline is at least as old as its European counterpart, having its beginnings with thework of Émile Cartailhac in Cambodia at the end of the nineteenth century (Forestier et al., 2012). Despite the interest that East and South Asia have generated, the evidence from India has been virtually ignored or dismissed (Mishra, 1994) and geopolitical events in China and Southeast Asia have unfortunately slowed scientific progress and its general diffusion. The presentation of material from the Bose Basin in South China by Hou et al. (2000) has brought more intense and continued attention from an increasing number of western paleoanthropologists to the Early Pleistocene archaeological record of East and Far-East Asia, particularly the presence of 'Acheulean-like' bifacial technologies beyond the eastern limits of the theoretical 'Movius Line'. The last decade has also seen an extraordinary new interest in initial human dispersal events 'Out-of-Africa' following recent discoveries of hominin fossils at Dmanisi (Vekua, 1995; Gabunia et al., 2000; Vekua et al., 2002; Rightmire et al., 2006) and Atapuerca (Carbonell et 
al., 1995; Bermúdez de Castro et al., 1997; Carbonell et al., 2008). These new discoveries, coupled with the recent 'opening' of such regions as Siberia and the wider diffusion of research carried out in China, has forced western paleoanthropologists to radically reconsider existing paradigms and modify views regarding the circumstances underlying the expansion of hominin groups from Africa (Carbonell et al., 2010). Such developments not only pose new questions concerning the emergence of particular hominin behavioral patterns, but increased interest in years of previous work in Asia has also raised issues surrounding the authorship of different assemblage types across the region.

While patterns of human dispersal can be traced to some extent in the fossil record, regional variations in lithic assemblage composition offermore numerous clues concerning such expansions. Although the exact role played by Asia in Pleistocene demographic processes is still unclear (Corvinus, 2004; Lycett and Norton, 2010), the region's archaeological record does shed new light on the evolution and spread of different human populations. Before discussing to what extent lithic technology influenced hominin dispersals (Braun et al., 2008), we review the relevant archaeological evidence from the region.

Three main regions of eastern Asia have produced evidence of very early hominin occupations: India (Pappu et al., 2011), China Zhu et al. 2001, 2003; Huamei et al., 2008; Hou and Zhao, 2010) and the Indonesian archipelago (Sémah et al.,1992; Morwood et al., 1998; Larick et al., 2001). Eustatic sea level variations throughout the Pleistocene (Voris, 2000) indicate that the Southeast Asian mainland was never submerged and likely functioned as a putative crossroads for the colonization of Southeast Asia (Pope et al., 1981). In fact, the potential of this key region located between India, China and the Indonesian archipelago had already been noted some time ago (see for example, Teilhard de Chardin, 1950).

Evidence for a lower or even Middle Pleistocene human presence in Burma, Thailand, Laos, Vietnam, Cambodia and Malaysia is sparse and often imprecisely dated with the oldest lithic material in continental Southeast Asia suggested to come from the open-air site of Lampang in Thailand, purportedly dated to more than $0.8 \mathrm{Ma}$ (Pope et al., 1986). The recent discovery of a series of stone tools spread across basalt deposits at Ban Don Mun in the Lampang province (northern Thailand) presents an ideal occasion for reevaluating not only the age of these artifacts, but reassessing the archaeological and geological context of the different lithic assemblages recovered from the Lampang localities during earlier fieldwork.

\section{Stone tools from the Lampang Basin}

Following the discovery of six artifacts from the site of Kao Pah Nam by Suchit Pitragol and work by the Thai-Danish prehistoric expedition (Sorensen, 1976, 1981), whose results were initially published in MacDonald and MacDonald (1976), Pope and colleagues documented stone tools from the Lampang province in Northern Thailand during surveys in 1978 (Pope et al.,1981) (Fig.1).

Several years before Pope's team began work in the area, Sorensen recovered more than 250 artifacts from the adjacent Mae Tha South locality (noted as MT I/II in Sorensen, 1976, 2001). Although the material housed at the National Museum of Chiang Mai has unfortunately gone missing since 1987, Keates (2001) has provided detailed descriptions of six artifacts (L-1, L-2, L-3 and MTS 86-1, 2, 3,Fig. 2) collected by Pope's team from an ancient river terrace embedded atop a laterite gravel deposit apparently overlain by basalt deposits $500 \mathrm{~m}$ south of where tools were initially found by Sorensen (Pope et al., 1981, 1986). At Ban Don Mun, basalt flows directly overlie gravel deposits purportedly containing cobble tools (Pope et al., 1986), however, only one artifact (BDM-86-1) was recovered from these deposits during the construction of a house (Sujit Pitragool, pers. comm.) and Mr. Champa Pananan, who dug the test-pit for Pope, indicated that no further stratigraphic information was recorded.

Stone tools documented from different localities near Lampang have been reported as the oldest yet found in Thailand (Sorensen, 1976; 2001; Pope et al., 1986), however, their stratigraphic position relative to the different basalt samples used to date them is either unreliable or not directly connected to the zones where archaeological material had been recovered. Despite at least two distinct basalt flows recorded at Ban Don Mun, one with reversed and one with normal polarity (MacDonald and MacDonald, 1976; see below), together with several dates produced by K/Ar (Sasada et al., 1987), no attempt has been made to directly date the Ban Mae Tha localities.

\section{Stratigraphy and dating of the Lampang material}

The material collected by Sorensen near Ban Mae Tha (Sorensen, 1976 p. 243) comes from the 'MTI/II' site located on the highest river terrace $(280 \mathrm{~m})$ (Fig. 1). The finds are described as being embedded in the top of a strongly lateritized pebble conglomerate overlain by riverine sands (ca. $30 \mathrm{~cm}$ thick). The conglomerate itself rests upon riverine sands spread uniformly across thick white-mottled clays interpreted 
as forming part of the original basin or representing the remnants of an older floodplain capping it. The 'MTS I' and 'MTS II' localities are surrounded by basalt toward the north, south and east, while the west opens onto the valley (Sorensen, 1976). Although Sorensen provides no indication of the exact whereabouts of the localities or a map, according to MacDonald and MacDonald (1976) the gravel deposit dips to the south and is overlain by basalt in a well $500 \mathrm{~m}$ to the south. The age estimate provided by Sorensen (2001) is based solely on the fact that the reverse-geomagnetized lowest flow of the Lampang basalt surrounding the MT I/II locality rolls over the edge of the oldest toolbearing terrace. This interpretation is also extended to the reverse-geomagnetized basalt flow that would also overly the toolbearing sediments at 'MT VI' demonstrating that at both sites "it can be shown clearly that the downcutting of the earliest terrace took place prior to the eruption of the basalt" (Sorensen, 2001: 138). The lateritization of the 'MTI/II' site has been taken to provide further support for the argument that the material derived from this locality is older than that from the 'MT VI' locality where no lateritization is observable. Pope et al. $(1981,1986)$ and Pope's $(1985)$ interpretation of the position of the stone tools was based on geological observations at some distance from the localities described by Sorensen. Concerning Mae Tha South, three artifacts (L-1, L-2, L-3) were supposedly collected in 1984 from fluviatile gravel deposits underlying the Lampang basalt. However, it should be recalled that the overlying Lampang basalt and the fluviatile gravels are observable in two wells located $150 \mathrm{~m}$ and $500 \mathrm{~m}$ south of this locality and that these three artifacts were found a few centimeters of each other within a matrix of red laterites and fluviatile gravels. The three other artifacts found in 1986 (MTS 86-1, MTS 86-2, MTS 86-3) are reported to have come from the same matrix (op. cit. 1986).

Besides paleo-magnetic data and a single fission track date from a basalt flow sample (with an error range of 100\%; MacDonald and MacDonald, 1976: 8), the first successful dating of the Lampang basalts (Sasada et al. 1987) proposed ages of $0.8-0.3 \mathrm{Ma}$ and $0.6-0.2 \mathrm{Ma}$. Both of these $\mathrm{KeAr}$ dates are instructive even if the dated samples derive from sources far from the localities described by Pope et al. $(1981,1986)$. Sample $82 Z 0401(0.8-0.3 \mathrm{Ma})$ is from a basalt pillow exposed along a railroad cutting $\left(18^{\circ} 15^{\prime} 30^{\prime \prime} \mathrm{N} 99^{\circ} 39^{\prime} 00^{\prime \prime} \mathrm{E}\right)$ north of Ban Mae Tha, while the date produced from sample 82Z0402 (0.6 - $0.2 \mathrm{Ma})$, collected from a massive basalt flow overlying gravel deposits (18 $\left.07^{\prime} 32^{\prime \prime} \mathrm{N} 99^{\circ} 37^{\prime} 52^{\prime \prime} \mathrm{E}\right)$, seems to fit better with the Mae Tha South localities. However, these samples are not in the direct vicinity of Ban Don Mun being, respectively, $11.1 \mathrm{~km}$ to the northwest and $5.7 \mathrm{~km}$ to the southwest of the site (Fig. 1). As the site of Ban Don Mun is located along the large, wide Nam Mae Chang Valley incised in a zone covered by 'Lampang basalts' (MacDonald and MacDonald,1976 ; Pope et al.,1986; Sasada et al., 1987), it seems unwise to generalize the situation from different sectors of the valley to all zones from which artifacts have been recovered. At Ban Don Mun, the basalt formation is several meters thick $(20 \mathrm{~m}$ at Huai Sala Wang Ngoen, however, the total thickness is generally unknown at Ban Don Mun itself), and constitutes a structural level (approximately 300-310 m) in the banks of the valley. The regional topography suggests that volcanic effusion covered an extremely flat landscape, probably alluvial in origin, however, the underlying deposits were not located and it is not certain if they are indeed alluviums (MacDonald and MacDonald, 1976). The Quaternary volcanic formations overlie the low-lying Triassic limestone and sandstone beds (in the area of the Pha Kan Formation), which themselves cover the substratum and older alluvial formations (cf. Geological Map of Northern Thailand; Hess and Koch, 1975). At Ban Don Mun (Fig. 3), formations west of the lava flow provide evidence for the development of a new alluvial terrace, about $15 \mathrm{~m}$ below the basalt and thus posterior to the deposition of the basalt level. The alluvial material is composed of pebbles and cobbles (from $5 \mathrm{~cm}$ to $20 \mathrm{~cm}$ in length) of quartzite and limestone contained within a heterogeneous matrix forming the topography surrounding the village of Ban Don Mun.

A single cobble-sized artifact (BDM 86-1) was recovered in situ at the Ban Don Mun locality from the upper part of the gravel bed, $66 \mathrm{~cm}$ below the soil surface, during construction of a house (Suchit Pitragool, pers. comm.) (Fig. 4). Two flakes were also found eroding onto the surface and may derive from the same horizon as the modified cobble according to Pope et al. (1981), however, it was not possible to establish the exact stratigraphic position of the artifact from Ban Don Mun or those from Mae Tha South as the latter were found "on an ancient river terrace, embedded in the top of a lateritized gravel deposit" (MacDonald and MacDonald, 1976: 2). The exact position of the previously documented lithic material and its association with the dated basalt flow therefore remains unclear.

\section{Description of the Lampang material}

It is not possible to describe the material discovered by the Thai-Danish prehistoric expedition as the sites have been destroyed (Sorensen, 2001: 140) and the material lost before having been illustrated. Nevertheless, Sorensen (1976: 249) notes that "at site MT. I/II in Lampang, chopping-tools only account 
for $2 \%$ of the total number of finds" and that " the number of tools from site MT.I/II amounts to over 250 ".

Based on the work of Dauvois (1976) and Inizan et al. (1999), our analysis of the Ban Don Mun and Mae Tha South material aims to recognize shaping or debitage methods, retouch procedures, as well as patterns in tool use, function and discard. In the case of the Lampang assemblages initially described by Keates (2001), the chaîne opératoire is quite simple involving a maximum of four major phases. The pieces described in greater detailed below are representative of the Lampang series as a whole.

\section{The MTS-86-1 cobble tool}

According to Keates (2001), MTS-86-1 was manufactured in quartzite and has four continuous, small to medium flake scars at an almost non-cortical end. Three shaping phases are evident (Fig. 5):

\section{Phase one}

Three large transverse flakes ( $\mathrm{n}^{\circ} 1,2$ and 3) were detached from a large ovoid cobble by way of a cortical/natural striking platform. These invasive removals (approximately two-thirds the width of the piece) run perpendicular to the piece's morphological axis with the proximal bulb negatives from the first phase serving as a striking platform for the second series of removals ( $n_{-} 4$ and 5 ).

Second phase

Cortical flakes 4 and 5 were detached in the opposite direction of the initial series $\left(n^{\circ} 1,2,3\right)$. The entire sequence $\left(\mathrm{n}^{\circ} 1-5\right)$ followed a basic shaping method employing a simple 'alternating platform system’.

Third phase

A cutting edge was created by a short retouch sequence, which began with a large flat removal $\left(n^{\circ} 6\right)$ intersecting the negatives of removals 1 and 3 from the first phase. Step fractures are visible on the left side of this surface. These removals served as a plain striking platform for the detachment of a series of concave flakes (group 7) creating the sharp cutting edge. The resulting cobble tool was created following a strict conceptual scheme evident in the initial search for a core with specific objectives and belongs to the category of tools with transverse cutting edges.

\section{The MTS-86-2 cobble tool}

Made in a fine-grained quartzite, MTS-86-2 is a bifacial tool bearing three continuous flakes detached at approximately an $80^{\circ}$ angle from one end of the convex face, while at the other end of the object a concave face shows three obliquely angled flake negatives (Keates, 2001). Four shaping phases were also involved in the production of this tool (Fig. 5):

First phase

A cobble with a beveled edge perpendicular to its morphological axis was selected based on its initial form.

Second phase

The beveled edge is predetermined by a single series of removals intended to delimit the eventual transverse cutting edge. These predetermined removals $\left(n^{\circ} 1\right)$ are generally situated on both or either lateral side of the medial part of the cobble's edge.

Third phase

Following this predetermination episode, the knapper sought a preexisting flat or slightly convex surface or, in this case, created one using a short series of flat and hinged removals $\left(\mathrm{n}^{\circ} 2 / 2^{\prime}, 3 / 3^{\prime}\right.$

and 4 according to their order of detachment, Fig. 5). This flat surface appears to have provided an effective cutting edge.

Fourth phase

The final shaping phase $\left(\mathrm{n}^{\circ} 5-8\right.$, Fig. 5) finished the active transverse edge by opposed invasive, concave removals.

\section{The MTS-86-3 cobble tool}

According to Keates (2001), this artifact had been split before the entire inner surface was extensively flaked. The worked face bears numerous stepped removals and is best described as a core. The MTS-86-3 cobble tool could be classified as a typical chopper, however, the association of a pre-sharpening phase followed by a more extensive phase was designed to produce a relatively open cutting angle with a planoconcave cross-section.

\section{The L-1, L-2 and L-3 cobble tools}

Both made of sandstone, L-1 and L-2 have been classified as cores by Keates (2001). L-1 has two large (with flaking angles ofw $8^{\circ}$ ) and two small flake scars. The ventral surface of L1 has two flake negatives, while that of L2 bears traces of only a single removal. L-3 was made on a fine-grained indurated conglomerate with a truncated end whose denticulated edge may represent use-damage. All three pieces 
are basic cobble tools: L-1 and L-2 are choppers and L-3 is a longitudinal fragment of cobble. The very typical L-1 cobble tool is shaped by four major convex and continuous removals delimiting a planoconvex cutting edge, while L-2 has a straight, continuous cutting edge with a clear asymmetry between the cobble's original morphological axis and the retouched part.

\section{The BDM-86-1 cobble tool}

This flaked cobble has three prominent scalariform flake negatives at one end (Keates, 2001) and can be described as denticulated chopper. The pre-sharpening phase comprised four removals (from the left to right) resulting in a beveled cutting edge that did not substantially reduce the cobble's initial volume.

In general, the Lampang material was recovered from three main localities (Kao Pah Nam, Ban Mae Tha South and Ban Don Mun) in the 1970s and 1980s. According to Sorensen (2001: 139),

the artifacts from MT.I/II are "somewhat older than the Brunhes-Matuyama boundary perhaps predating the Jaramillo Event" and the material from MT.VI "also belongs the Early Pleistocene period, but only just predates the Brunhes-Matuyama boundary or Jaramillo Event", while the artifacts from Mae Tha South and Ban Don Mun mentioned by Pope (Pope et al., 1981, 1986; Pope, 1985) have been interpreted as being older than $0.8 \mathrm{Ma}$ based on the indirect dating of basalt layers at some distance from the find spots. Finally, no stratigraphic information is available for the Kao Pah Nam series.

\section{New lithic artifacts from Ban Don Mun}

Recent fieldwork carried out by the Thai-French Paleosurvey between 2005 and 2012 documented 25 new lithic artifacts recorded exclusively from the top of the basalt formation at Ban Don Mun, along with one new artifact from Ban Mae Tha (Fig. 4). The most significant pieces recovered from Ban Don Mun (N $18^{\circ} 9^{\prime} 30^{\prime \prime} \mathrm{E} 99^{\circ} 40^{\prime} 30^{\prime \prime}$ (Fig. 6) can be classified into the same groups and types as the artifacts originally collected by the Thai-American Expedition, as well as those from Kao Pah Nam documented by Sujit Pitragool (Table 1) or the series presented by Sorensen (1976: 249). These include choppers, choppingtools, pieces with convergent edges and the occasional small flake made on a similar brownish, finegrained quartzite. The raw material employed is frequently available in the form of pebbles and cobbles from local terrace deposits at Lampang, Phrae and also in the Nanoi intermountain basins. Differences between chopper-chopping tool complexes and assemblages from elsewhere in the world was partially explained by Movius (1943) as resulting from differences in available raw materials together with clear similarities between artifacts from Myanmar (Movius, 1943) and Cambodia (Saurin, 1966) made on the same raw material.

Direct hard-hammer percussion, the use of identical raw materials (mostly fine-grained quartzite) and a similar shaping method applied to large cobbles are all typical of the sites from the Lampang Basin (i.e., Mae Tha South, Kao Pah Namand Ban Don Mun localities). While this material is generally considered to represent a basic Lower Pleistocene cobble assemblage (Pope et al., 1981; Sorensen, 2001), at least one artifact from Ban Don Mun nevertheless provides new data and poses new questions concerning interpretations of the region's lithic assemblages. This unique piece (Fig. 6, v) can be described as a 'cortical trihedral pick', a type of pointed chopper manufactured on an elongated cortical cobble with a triangular cross-section (Fig. 7). This cobble tool is similar to an elongated handaxe with its symmetrical and elongated morphology providing evidence for the emergence of a new concept of axial symmetry associated with a trifacial shaping method. Three similar pieces were apparently collected, but never illustrated by Sorensen (1976: 249) from the PS III site in the Phrae

Basin near Lampang however "the Phrae sites cannot be dated in absolute terms" (Sorensen, 2001: 139).

\section{Stratigraphy and dating of the new material from Ban Don Mun}

New lithic material collected by the Thai-French Paleosurvey (Fig. 8) from Ban Don Mun was found directly on the surface of a basalt flow or from sediment depths of $10-22 \mathrm{~cm}$, but always on the upper part of the basalt flow (Fig. 4). The trihedral pick discussed above (Fig. 6, v) was discovered in a vertical position, $22 \mathrm{~cm}$ below the soil surface in a basalt fissure.

The artifacts from Ban Don Mun were found on a basalt flow dated using K-Ar to $0.55 \pm 0.01 \mathrm{Ma}$ by the Korean Basic Science Institute (Table 2). The K component was measured using an inductively coupled plasma atomic emission spectrometer (ICPAES) and conventional wet chemistry. Multiple runs of chemical standard (JGR-1) indicate that the accuracy and reproducibility of this method are within $2 \%$. Argon was analyzed on a $90^{\circ}, 54 \mathrm{~cm}$ radius sector type mass spectrometer (VG5400) with a double collector system (high Faraday collector and electron multiplier) operated at an accelerating potential of $4.5 \mathrm{kV}$ and trap current of $200 \mathrm{~mA}$ using an isotopic dilution method and a 38Ar spike. Age calculations and error were assessed using the method described by Nagao et al. (1996). Standard analyses of a sample batch both before and after argon analyses ensured accuracy to be within $2 \%$, the error of each age 
determination, with the bulk KeAr age of the flow basalt being $0.55-0.01 \mathrm{Ma}$ (see Table 2 for more detail). As the $\mathrm{K}-\mathrm{Ar}$ age determination does not discriminate loss and/or excess of argon, comparisons with other chronological evidence are indispensable for adequately assessing the geo-chronological context of the material. Nevertheless, our dataset provides new, more precise chrono-cultural information, especially concerning the position of the artifacts on the top of the basalt flow. This new date, coupled with the reverse magnetic polarity of the oldest basalt flow (Barr et al., 1976; MacDonald and MacDonald, 1976; Pope et al., 1986), further supports the recurrence and significant duration of the basalt effusions overlying Triassic limestone and sandstone comprising the lower and Middle Pleistocene Pha Kan Formation in the Lampang province. The stratigraphic position of the artifacts recovered during our fieldwork at Ban Don Mun is well documented (Fig. 4); all the material was found exclusively on the surface of the basalt and therefore cannot pre-date the deposition of the basalt flow. Some confusion regarding the interpretation of the alluvial cobbles forming the recent terrace and localities overlain by basalts in other areas is clearly evident in Pope et al.'s $(1981,1986)$ assessment of the artifacts' context. Furthermore, artifact BDM 86-1 was found during construction work near the structural edge of the basalt flow and has no precise stratigraphic context other than being found below the basalt level in contact with the alluvial formations. Uncertainties in the available archaeological data and its association with the local geology do not allow a precise assessment of the antiquity of the lithic artifacts previously recovered near the basalt formations at Mae Tha South, Kao Pah Namor Ban Luang. Our work at Ban Don Mun does however shed new light on the fact that some stone tools are more recent than the basalt deposits near where they were recovered and thus much younger than others formerly reported.

\section{Discussion}

It is fundamental that the precise nature and chronology of relevant lithic assemblages be established before they are integrated within models of human dispersal and expansion. Discoveries of 'archaic' cobble industries without a bifacial component in northern India, Myanmar, Thailand, Laos, Vietnam and China formed the original basis of Movius' theory, (Movius, 1944, 1948) later simplified into the concept of the 'Movius Line' separating two lower Paleolithic cultural traditions; a western one extending to northern India (Punjab) with bifacial features similar to African assemblages (Rendell et al., 1989; Mishra, 1992; Gaillard, 1996; Gaillard et al. 2008, 2010) and a second one in the east encompassing China and other East and Southeast Asian regions where only chopper and chopping-tool industries had been documented.

The presence of bifacial tools in the Bose Basin, as well as in the middle and western regions of China or Korea (Yi and Clark, 1983; Hou et al., 2000; Derevianko, 2008), coupled with discoveries of cleavers in the Chinese Luonan Basin (Wang, 2006), has led some scholars to suggest a 'Movius Line sensu lato' (e.g., Norton and Bae, 2008). Nonetheless, the Movius Line in either guise remains the subject of considerable debate (Keates, 2002; Corvinus, 2004; Norton et al., 2006; Petraglia and Shipton, 2008; Chauhan, 2011) resulting from the sparsity of relevant sites with handaxes and issues surrounding the percentage of bifaces in certain assemblages. For example, Corvinus (2004: 146e147) has argued that samples "from the various sites at the Bose Basin taken together is too small (only a few amongst the thousands of cobble tools and flakes) to warrant calling them Acheulean" and that "large bifacial pointed tools and so-called handaxes of East and Southeast Asia are considered to be a byproduct of a heavy cobble tool industry and can be expected during stone knapping. They are a minor element, not an endpoint, of the preconceived tool concept of the toolmakers of the Homo erectus time in East- and Southeast Asia". Some confusion is inevitably connected to tool morphology, which led Movius (1943) to suggest replacing 'handaxe' by 'handadze' to describe stone artifacts from the Burmese Early Anathyan. Boriskovsky (1971) later criticized this 'theoretical' line for assuming that absence of evidence for bifacial artifacts is not evidence of absence with the additional reproach that researchers either ignore or disparage bifacial artifacts from East Asia (Hutterer, 1977). While continental Southeast Asia does indeed still lack welldated biface industries, this type of assemblage is documented at the site of Mont Do in Vietnam (Huy Thong, 1976; Van Tan, 1980). Similar discoveries in Xuan Lôc, also in Vietnam, during the 1970s (Saurin, 1971) ought to have dispelled the theoretical 'Movius Line' shortly after Bordes (1968) brought it to more general attention. Southward in insular Indonesia, numerous lithic assemblages containing bifaces, bifacial pieces, cleavers or large scrapers with bifacial retouch are also well documented. Found principally in Eastern Java in the Baksoko River deposits near Pacitan, these socalled 'Pacitanian' assemblages produced by Javanese H. erectus are composed of bolas, large flakes and cleavers associated with Stegodon faunas (Sémah et al., 1992; Sémah, 2001). Excavations at the site of Ngebung 2 in Central Java place the Pacitanian to around $0.8 \mathrm{Ma}$. Pleistocene material has also been documented in southwestern Sulawesi at Cabenge and more 
recently in the Ogan River Valley near Baturaja on the island of Sumatra (Forestier et al., 2005; Simanjuntak and Forestier, 2008). Moreover, a recent regional synthesis (Dizon and Pawlik, 2010) has noted that lithic material consisting mostly of unretouched flakes, choppers and other unifacially retouched pebble tools have been discovered in the Cagayan River Valley in Northern Luzon in Philippines since the 1950s. However, the chronological association of this lithic material with Pleistocene fauna is still a matter of some debate (Pawlik and Ronquillo, 2003). The first bona fide handaxe was discovered in 1996 along with a large flaked artifact and fossilized wood recovered at Arubo in Central Luzon. While the composition and variability of bifacial toolkits from Africa and Eurasia are much better understood, Southeast Asia is yet to divulge the complete mystery of its lithic technology.

Strictly speaking, the issue of the Movius Line itself can not be resolved simply with reference to Ban Don Mun as the site yielded no bifacial pieces. Furthermore, we have clearly demonstrated that the lithic assemblage belongs to the Middle, rather than Lower Pleistocene. Our results nevertheless help clarify chronological aspects surrounding the duration and geography of this so-called 'line'. In fact, cobble tools form the major component of lithic assemblages up until very recent periods in the area described by the 'Movius Line' suggesting that the region discussed here perhaps followed a completely different cultural trajectory than did a large portion of the rest of the world. If some Middle Pleistocene hominin groups who occupied Southeast Asia could shape a trifacial/trihedral axe, they also likely possessed the cognitive capacity and skills necessary to shape 'hand-axes' as the technical threshold between trifacial and genuine bifacial strategies is quite small: a simple question of symmetry. In addition to Ban Don Mun, trifacial pieces had already been documented in Thailand from the Phrae Basin (Sorensen, 1976: 139) as well as from Shanxi in China, however, they have been described as "heavy points, which may be typologically classified into trihedral and pick-like forms [and] are considered index fossils of the Dingcun Middle Paleolithic" (Qiu, 1985: 191). Pioneering surveys and studies carried out several decades earlier had already highlighted the archaeological potential of Southeast Asia (Sarasin,1933; Movius,1943; Van Heekeren,1947; Heider, 1960; Saurin, 1963a, b, 1966; 1971; Saurin and Carbonel, 1964; Boriskovsky, 1966; Carbonel, 1972), suggesting that the likely discovery of Pleistocene bifacial pieces or 'genuine' handaxes to not be too far behind even if, as demonstrated elsewhere in the world (Soriano, 2003; Yi, 2011 see also; Pawlik and Ronquillo, 2003), archaic does not necessarily mean ancient. The challenge will be providing a sound chronological framework for these new discoveries such that they can be integrated in current models of human expansion in the region.

\section{Conclusion}

It is now clear that the choppers, chopping-tools, convergent points, the occasional small flake and the trihedral pick recovered from Ban Don Mun are younger than the underlying basalt flow dated to 0.55 $\mathrm{Ma}$, independent of dates for the material collected from the other Lampang sites. These archaic lithic industries provide new clues for a Pleistocene human presence in northern Thailand and may represent evidence of divergent cultural trajectories in Southeast Asia possibly constrained by demographic factors (Lycett and Norton, 2010) and mediated by environmental conditions, especially the availability of bamboo, hardwood and rattan as suggested by numerous researchers (Gourou, 1948; Gorman, 1970; Boriskovski, 1971; Van Heekeren, 1972; Solheim, 1972; Hutterer, 1977; Westergaard and Suomi, 1995). The local emergence of bifacial industries during the Middle Pleistocene cannot be ruled out and may correspond to the dispersal of multiple hominin groups (Zeitoun et al., 2010) into the region as early as 1.9 Ma (Huang et al., 1995). From a wider regional perspective, the eventual discovery of equally early sites in continental Southeast Asia would come as no surprise given the presence of very early industries in Pakistan at the site of Riwat dated to around 2.5 Ma (Rendell and Dennell,1985; Dennell, 2009), in southern India at Attirampakkam, which is older than 1.5 Ma (Pappu et al., 2011), Southern China with Longgupo dated to over 2.0 Ma (Hou and Zhao, 2010; Boëda and Hou, 2011) and insular Southeast Asia with Pacitan in Java (Sémah et al. 2000) and the Mata Menge site in Flores around 0.8 Ma (Sondaar et al., 1994; Van den Bergh et al., 1996; Morwood et al., 1998; Simanjuntak et al., 2010). This probability has already been hinted at by earlier discoveries in Myanmar (Movius, 1943), Cambodia (Saurin, 1966) and Thailand (Sarasin, 1933; Van Heekeren, 1947), further reinforced by more recent finds from Northern Thailand (Zeitoun et al. 2012). 


\section{Acknowledgements}

We would like to thank C. Gaillard, B. Gravina and two anonymous reviewers for constructive comments, as well as A. Pierret, T. O. Pryce. We are also grateful to A. Lenoble, J. Thompson, N. Mercier, J.H. Choi and M. Mailliez for their contribution to the Lampang field survey and S. Pitragool, S. Nakbunlung and C. Pananan for providing relevant firsthand information. This work has been supported by the Commission for Archaeological Exploration of the Ministry for Foreign and European Affairs in Paris.

\section{Figure captions}

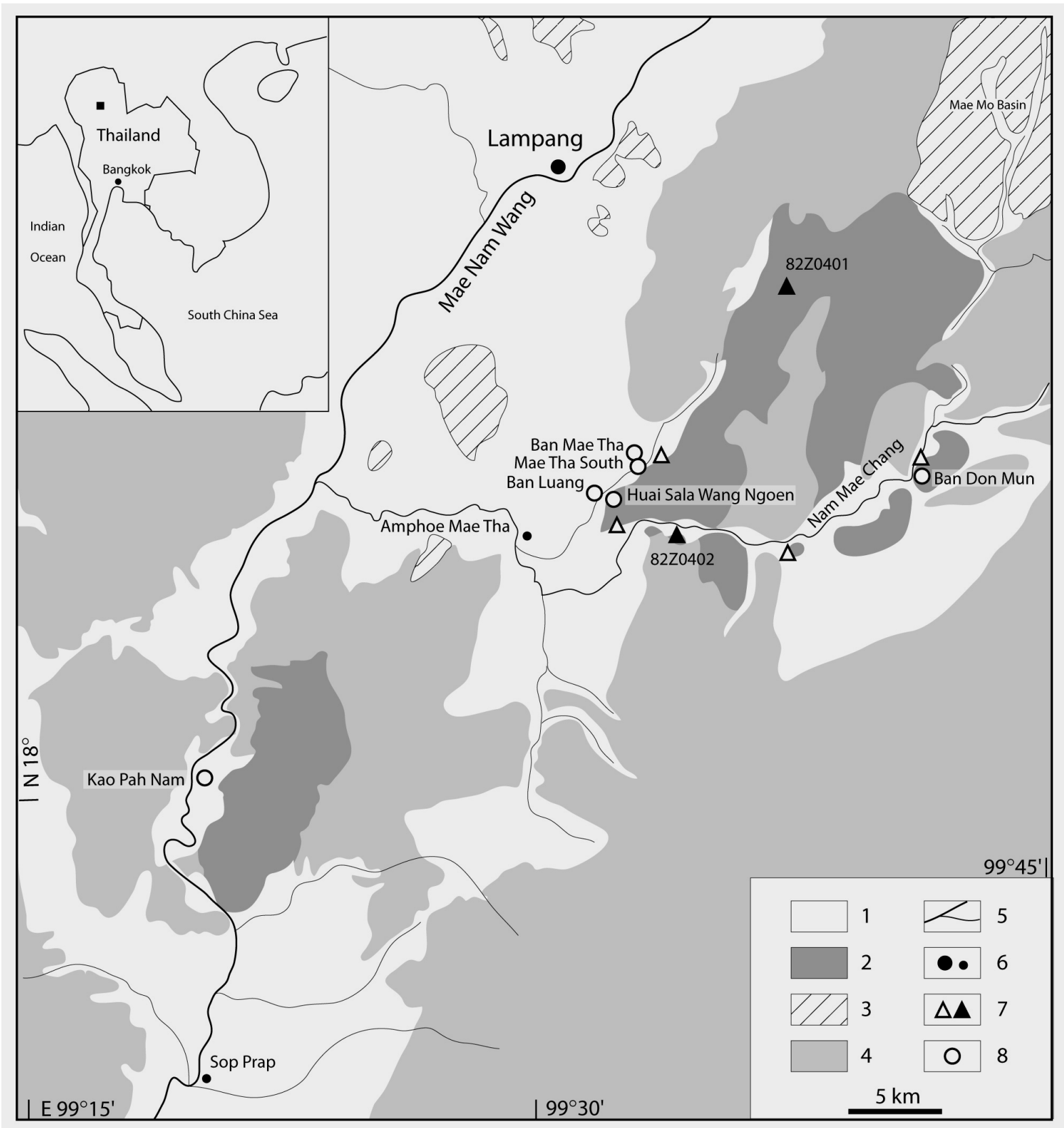

Figure 1: Location of the Ban Don Mun site and other Lampang localities mentioned in the text.

1) Undifferentiated Quaternary deposits; 2) Quaternary basalts; 3) Tertiary; 4) Undifferentiated preTertiary deposits; 5) Hydrographic network; 6) Major cities; 7) Location of radiometric samples (Pope et al., 1986 (in white) and Sasada et al., 1987 (in black)); 8) other known archaeological sites. 


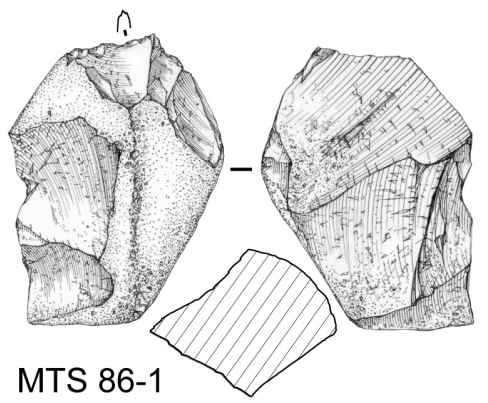

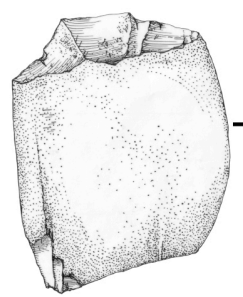

MTS 86-2
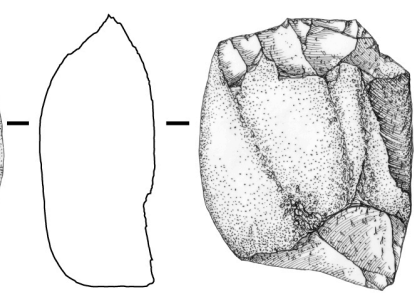

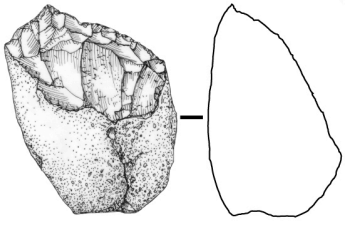

MTS 86-3

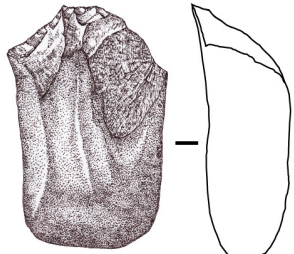

$\mathrm{L}-1$

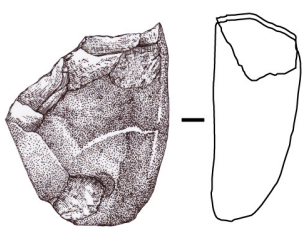

$\mathrm{L}-2$
$10 \mathrm{~cm}$

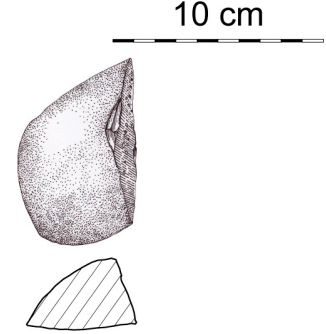

$\mathrm{L}-3$

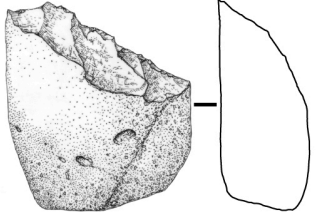

BDM 86-1

Figure 2: Stone tools recovered from Mae Tha South (MTS and L) and Ban Don Mun (BDM) by the Thai-American Expedition in Northern Thailand.

MTS 86-1: Bifacial cobble tool with a convergent cutting edge; MTS 86-2: Large cobble tool with a straight, transverse cutting edge created by bifacial retouch; MTS 86-3: Unifacial cobble tool with a convergent cutting edge; L-1: Unifacial cobble tool with a convex, transverse cutting edge; L-2: Unifacial cobble tool with a transverse, oblique cutting edge; L-3: Longitudinally fractured cobble. BDM86-1: Unifacial cobble tool with a transverse, obliquely denticulated cutting edge. 


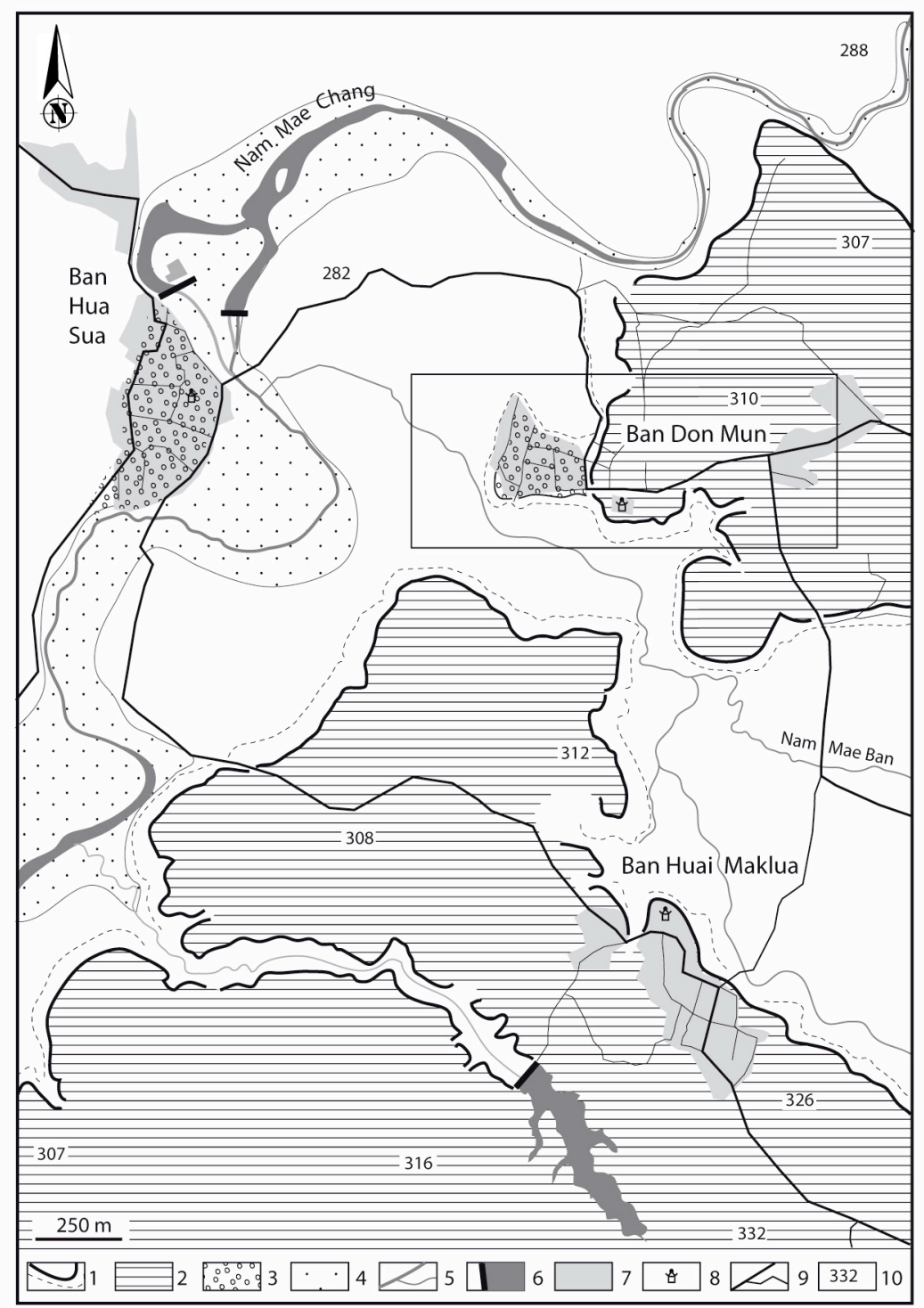

Figure 3: Geomorphology of the Nam Mae Chang Valley.

1) Break slope 2) Basalt plateau; 3: Alluvial terrace; 4) Low alluvial plain (in white); 5) Hydrological system;

6) Reservoir/lake; 7) Built-up areas; 8) Temple (wat); 9) Main roads; 10: Altitude (m). 

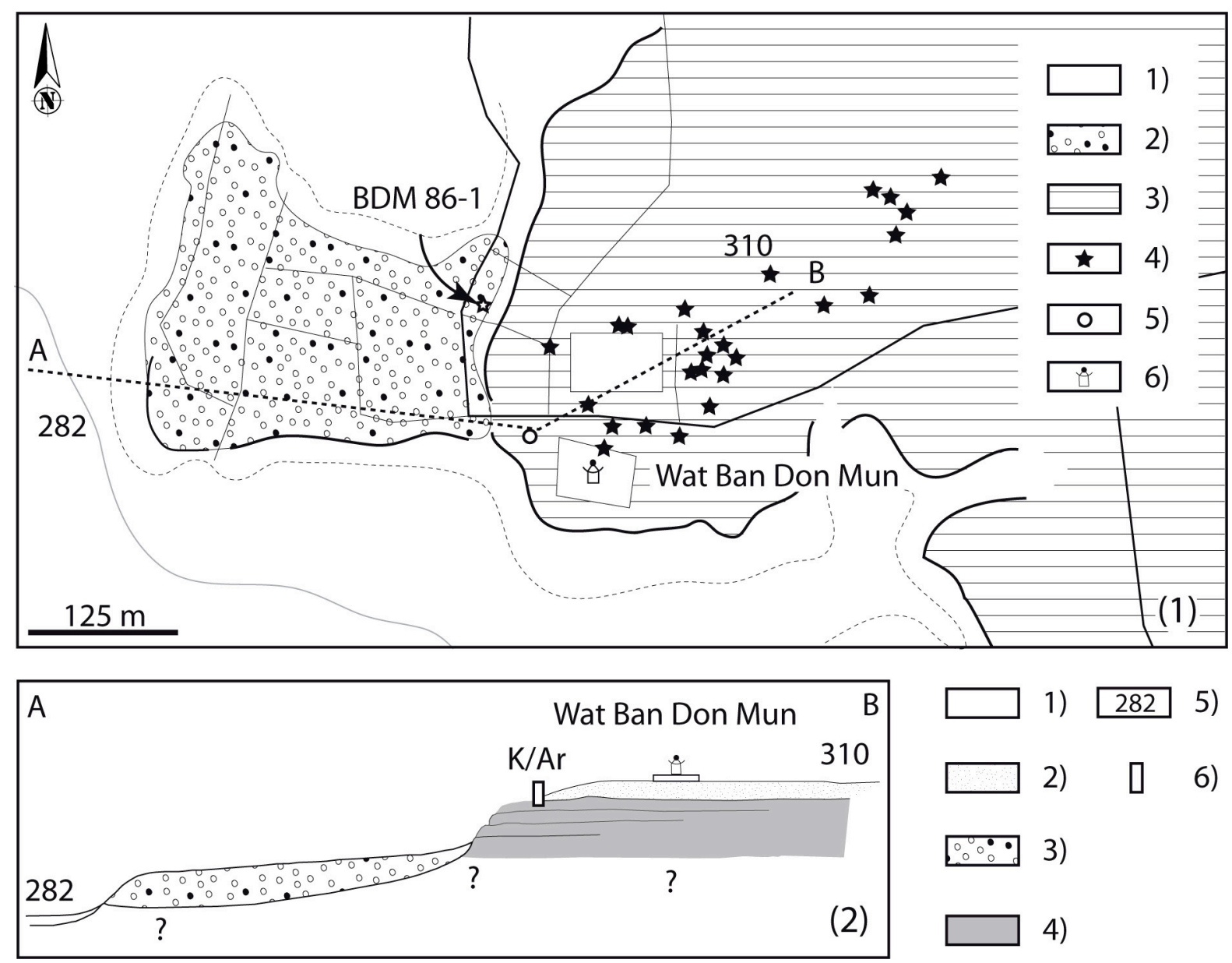

Figure 4: Location and stratigraphic context of the Ban Don Mun sector. (1) Detail of the location 1) Alluvial plain; 2) Alluvial terrace; 3) Basaltic structural plateau; 4) Location of artifacts; 5) Location of radiometric samples; 6) Temple of Ban Don Mun.

(2) Profile 1) Alluvial plain deposits; 2) Coarse alluvial sands and altered basaltic level; 3) Alluvial gravel formation; 4) Basalt; 5) Altitude in meters; 6) Location of radiometric samples. 

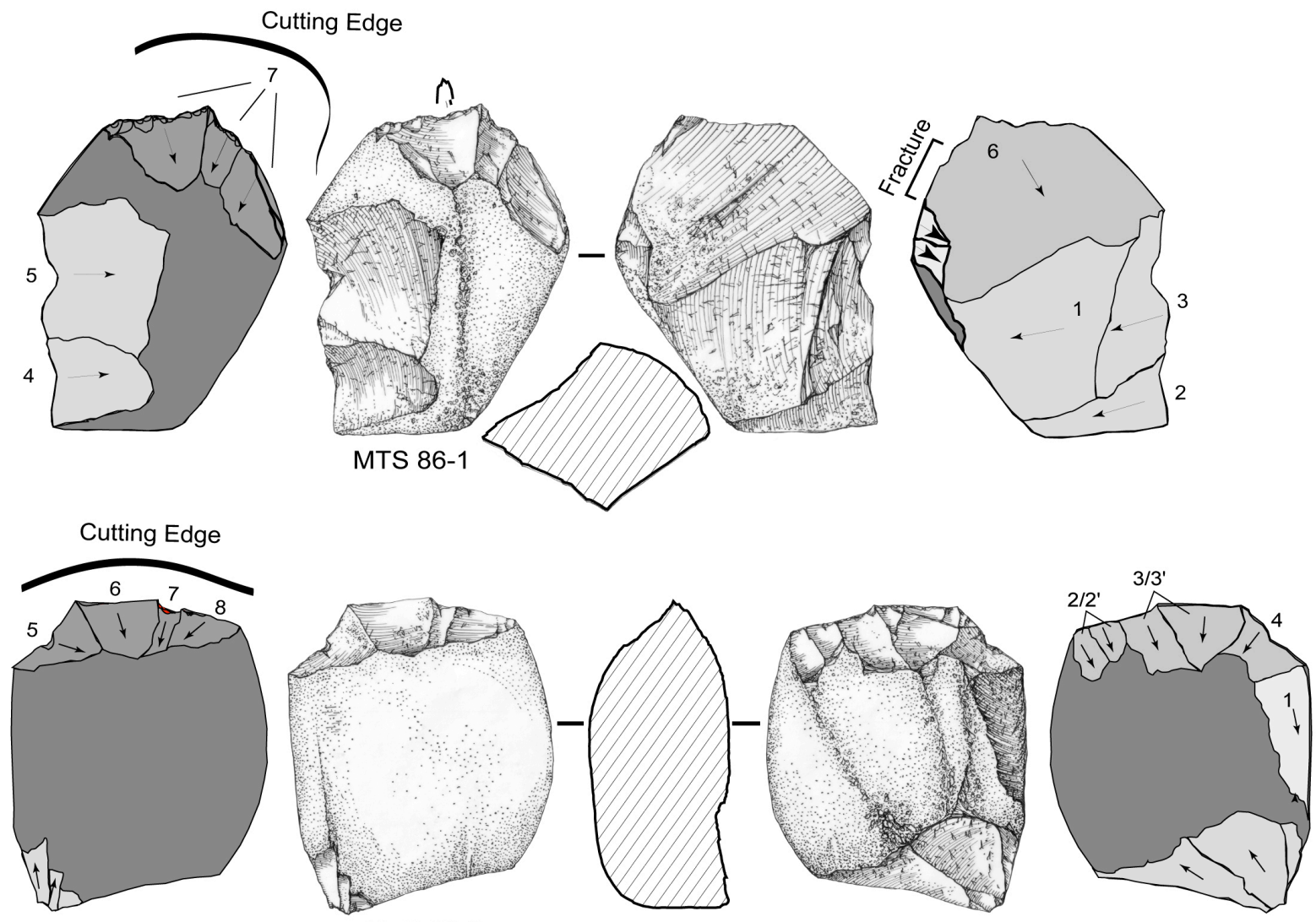

MTS 86-2

Figure 5: Diacritic diagrams of MTS-86-1 and MTS-86-2 cobble tools. 


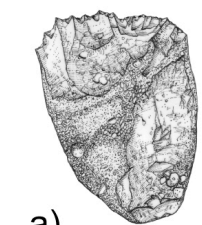

a)

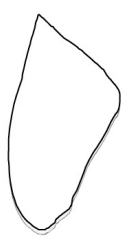

b)

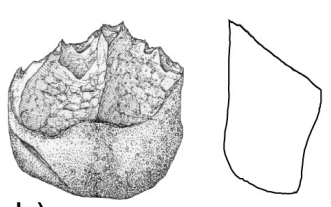

e)

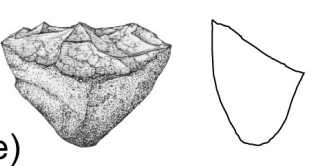

i)
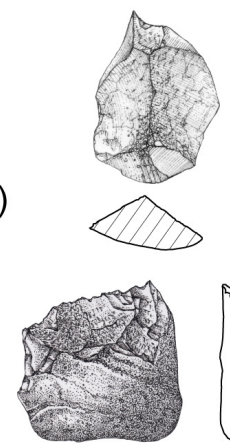

m)

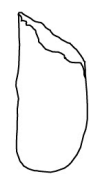

n)
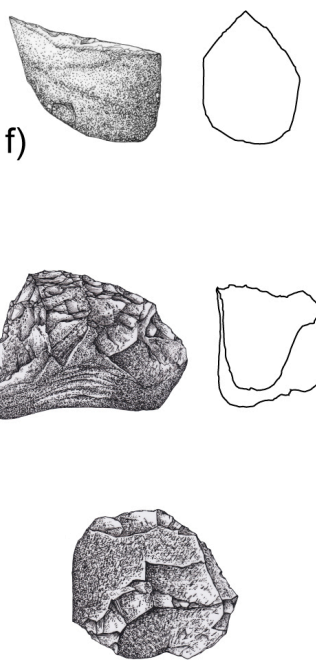

g)

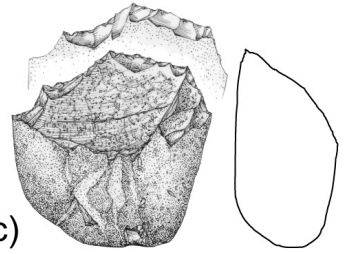

c)

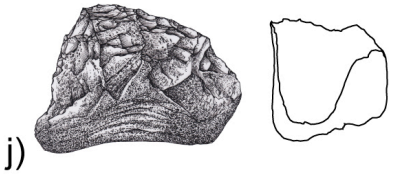

k)

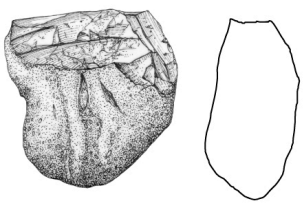

h)

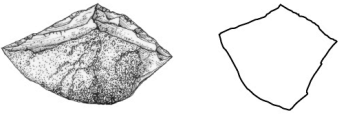

d)

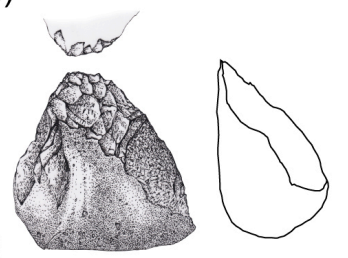

I)

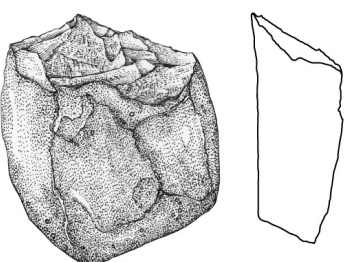

o)
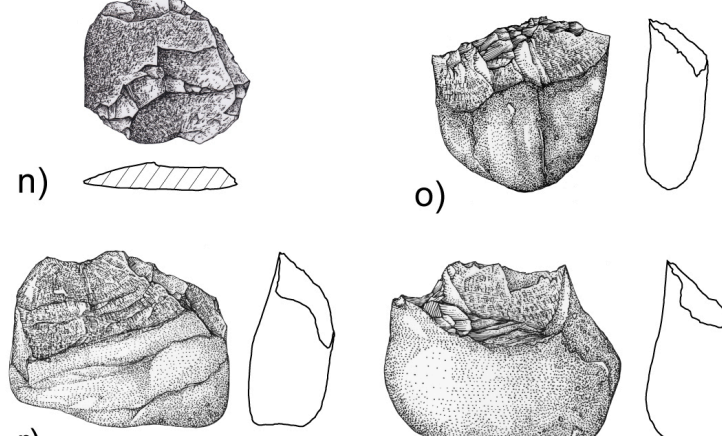

r)

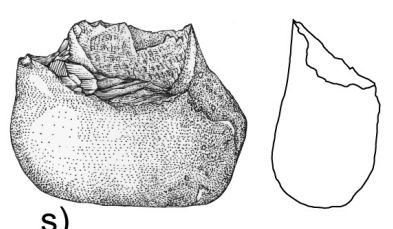

s)

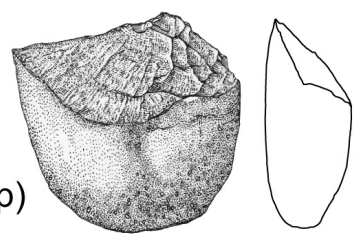

t)
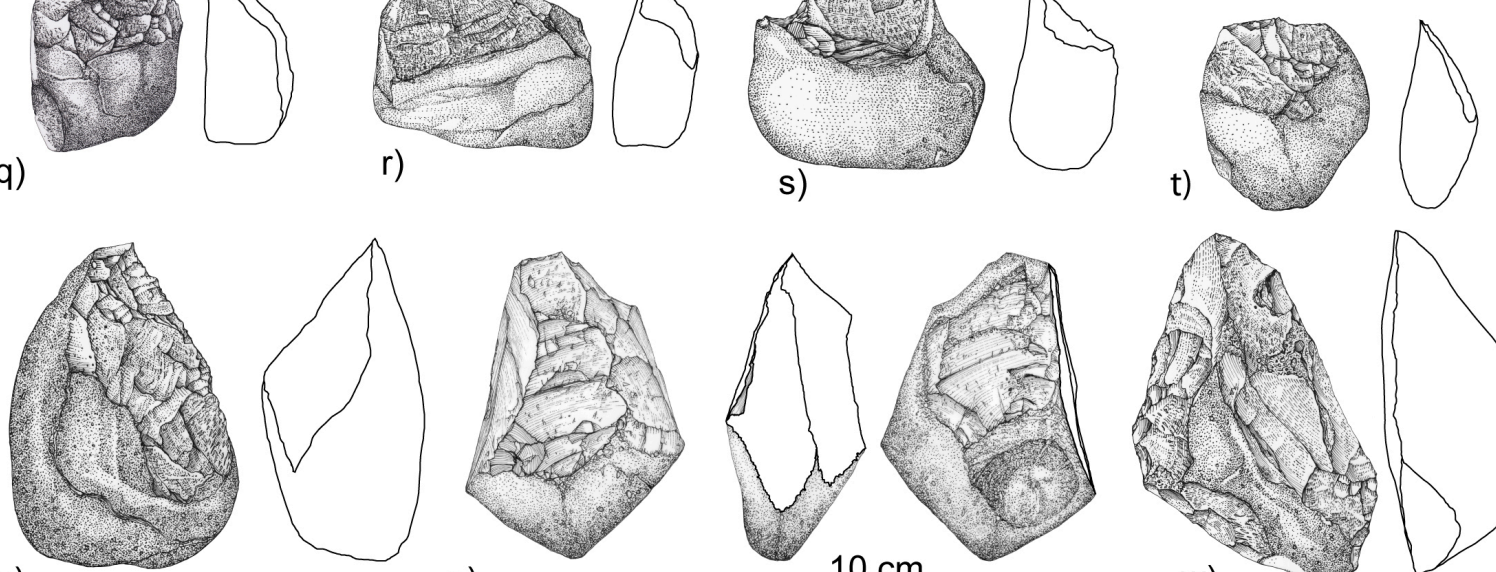

u)

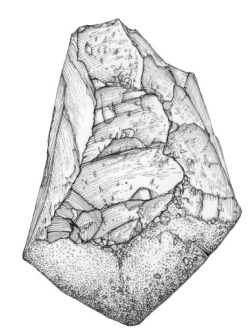

v)

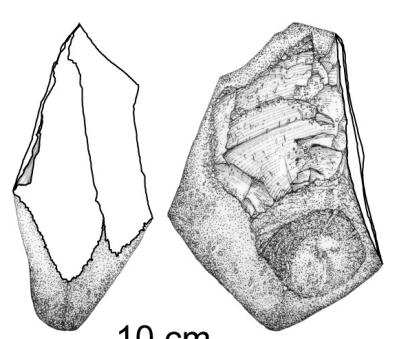

$10 \mathrm{~cm}$

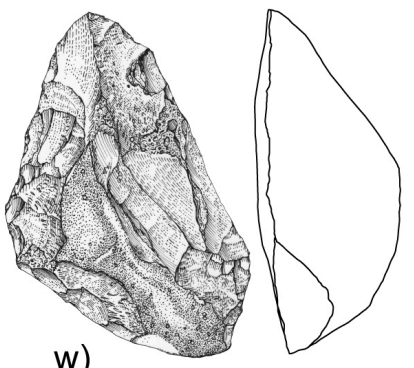

w)

Figure 6: Stone tools recovered from Ban Don Mun (BDM) by the Thai-French Paleosurvey.

A-d, e, g, k-m, o-t): Choppers; d) : Chopping tool; f): Fractured cobble; h) : Convergent point; i): Flake; j) : Convergent point ; n) : u): Lateral chopper; v): Trihedral pick; w): Convergent point. 

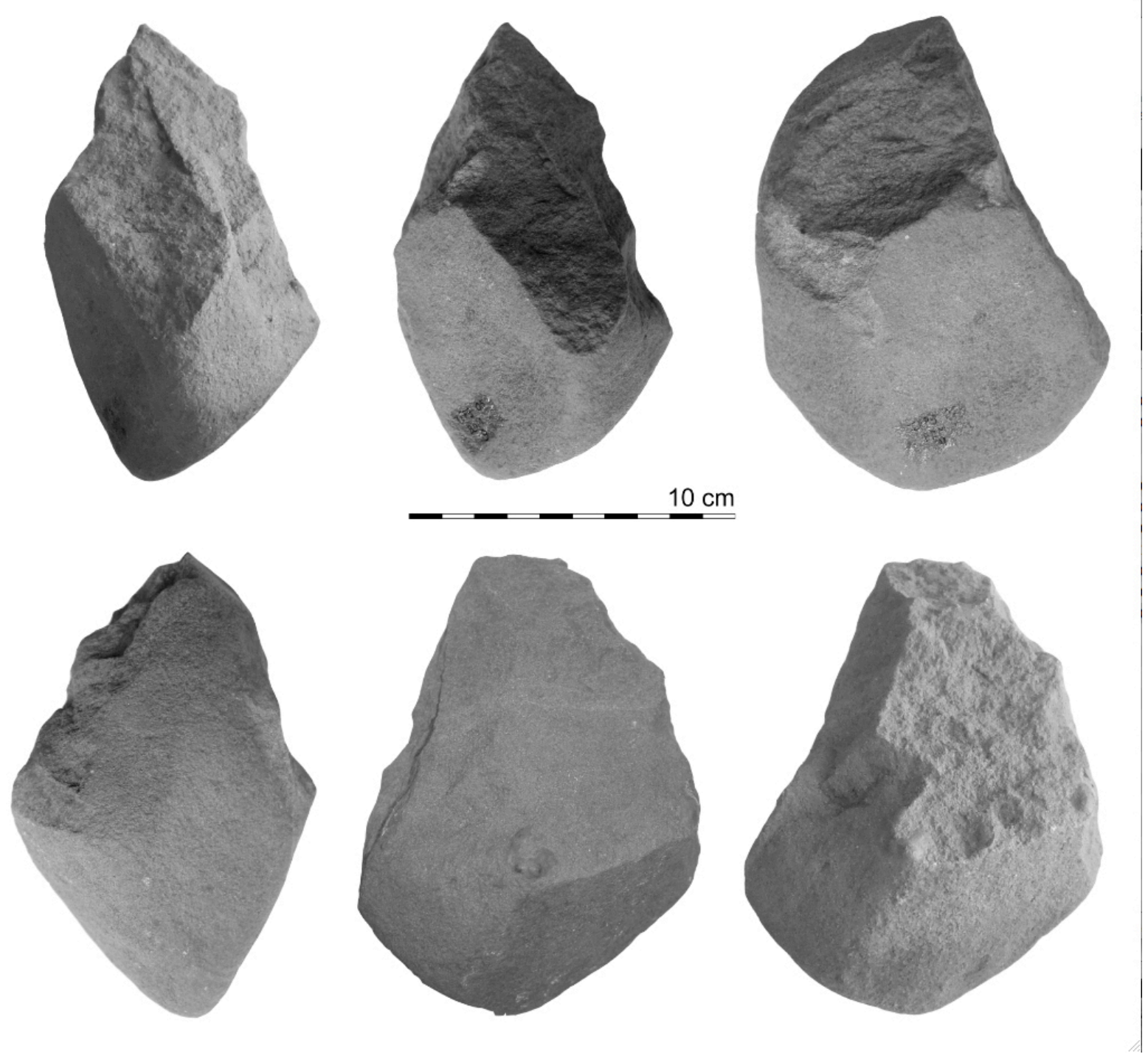

Figure 7: Trihedral pick (BDM n 09 ) 


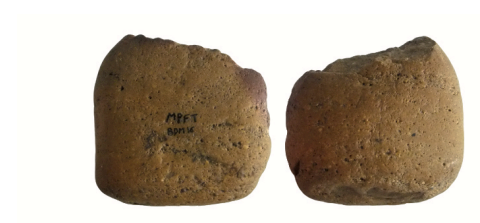

TFP BDM 16

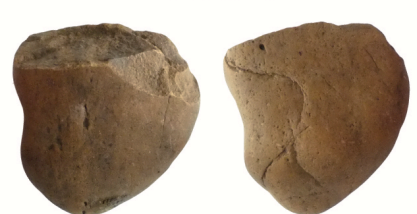

TFP BDM 8

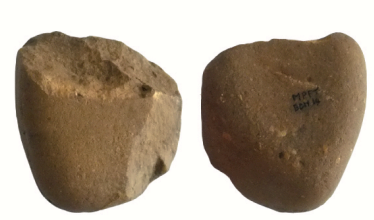

TFP BDM 14

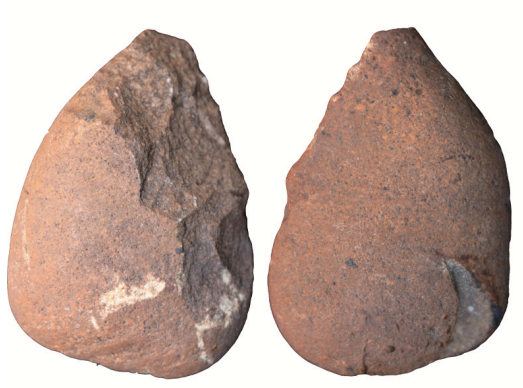

TFP BDM 23

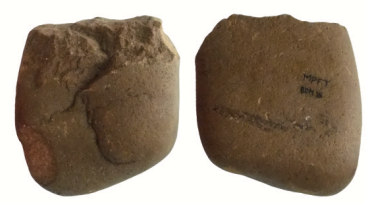

TFP BDM 15

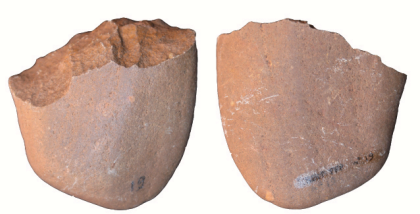

TFP BDM 19

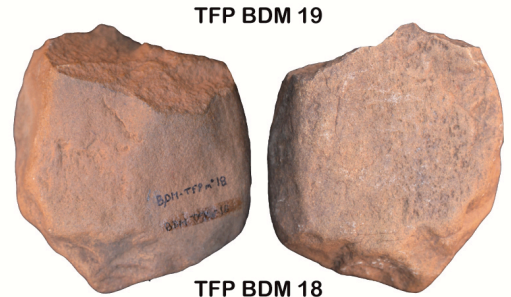

TFP BDM 18

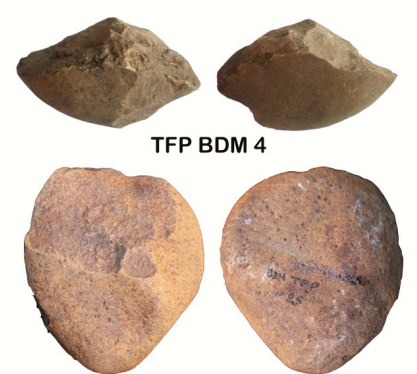

TFP BDM 25

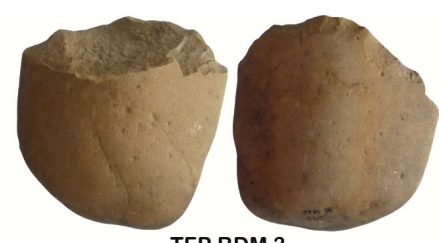

TFP BDM 3

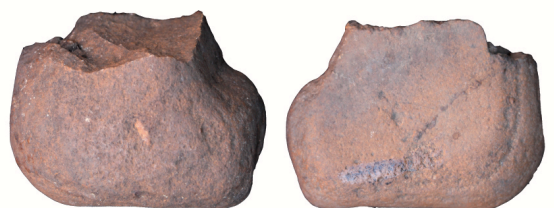

TFP BDM 22

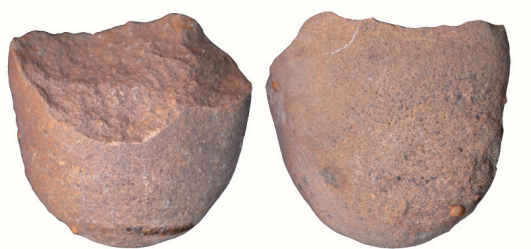

TFP BDM 20

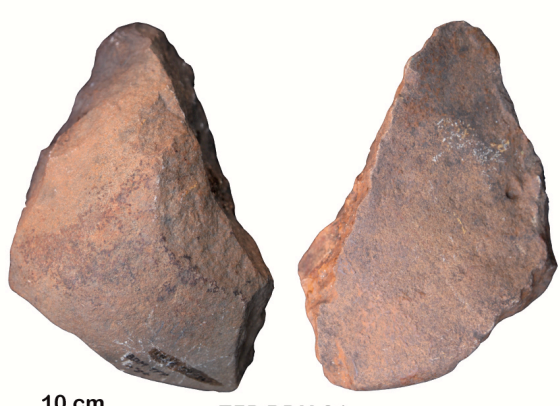

Figure 8: Artifacts collected by the Thai-French Paleosurvey from Ban Don Mun locality. 


\begin{tabular}{|c|c|c|c|}
\hline Different series & Length & Width & Thickness \\
\hline Chiang Mai University & \multicolumn{3}{|c|}{ measures in $\mathrm{mm}$} \\
\hline KPN 85-2 & 93 & 89 & 29 \\
\hline Thai-American Expedition & \multicolumn{3}{|c|}{ measures in $\mathrm{mm}$} \\
\hline$L-1$ & 140 & 104 & 89 \\
\hline $\mathrm{L}-2$ & 132 & 104 & 56 \\
\hline$L-3$ & 103 & 74 & 64 \\
\hline MTS 86-1 & 115 & 76 & 39 \\
\hline MTS 86-2 & 95 & 76 & 40 \\
\hline MTS 86-3 & 91 & 57 & 34 \\
\hline BDM 86-1 & 101 & 89 & 44 \\
\hline Thai-French Paleosurvey & \multicolumn{3}{|c|}{ measures in mm } \\
\hline $\mathrm{BDM} \mathrm{TFP} \mathrm{n}^{\circ} 01$ & 107 & 71 & 50 \\
\hline BDM TFP n ${ }^{\circ} 02$ & 81 & 83 & 45 \\
\hline BDM TFP n ${ }^{\circ} 03$ & 93 & 94 & 48 \\
\hline BDM TFP n04 & 48 & 80 & 56 \\
\hline BDM TFP n05 & 59 & 80 & 43 \\
\hline BDM TFP n06 & 75 & 59 & 54 \\
\hline $\mathrm{BDM}$ TFP $\mathrm{n}^{\circ} 07$ & 59 & 73 & 46 \\
\hline BDM TFP n08 & 86 & 82 & 42 \\
\hline BDM TFP n09 & 150 & 101 & 66 \\
\hline BDM TFP $n^{\circ} 10$ & 79 & 67 & 41 \\
\hline BDM TFP $n^{\circ} 11$ & 82 & 58 & 25 \\
\hline BDM TFP $n^{\circ} 12$ & 98 & 99 & 58 \\
\hline BDM TFP $n^{\circ} 13$ & 83 & 112 & 62 \\
\hline BDM TFP $n^{\circ} 14$ & 94 & 84 & 39 \\
\hline BDM TFP n ${ }^{\circ} 15$ & 94 & 83 & 47 \\
\hline BDM TFP $n^{\circ} 16$ & 89 & 90 & 40 \\
\hline BDM TFP $\mathrm{n}^{\circ} 17$ & 83 & 89 & 15 \\
\hline BDM TFP $n^{\circ} 18$ & 117 & 101 & 40 \\
\hline BDM TFP n ${ }^{\circ} 19$ & 90 & 91 & 30 \\
\hline BDM TFP n ${ }^{\circ} 20$ & 106 & 111 & 42 \\
\hline BDM TFP n ${ }^{\circ} 21$ & 90 & 112 & 42 \\
\hline BDM TFP n ${ }^{\circ} 22$ & 89 & 109 & 48 \\
\hline BDM TFP n ${ }^{\circ} 23$ & 154 & 109 & 77 \\
\hline BDM TFP n²4 & 171 & 121 & 71 \\
\hline $\mathrm{BDM}^{\mathrm{TFP}} \mathrm{n}^{\circ} 25$ & 93 & 84 & 37 \\
\hline
\end{tabular}

Table 1: Metric data for material collected in the Lampang province. 


\begin{tabular}{|c|c|c|c|c|c|c|}
\hline $\begin{array}{c}\text { Sample } \\
\text { name }\end{array}$ & $\begin{array}{c}\mathrm{K} \\
(\mathrm{wt} \%)\end{array}$ & $\begin{array}{c}\text { Sample } \\
\text { weight } \\
(\mathrm{mg})\end{array}$ & $\begin{array}{c}{ }^{40} \mathrm{Ar} \text { (radiogenic) } \\
\left(10^{-8} \mathrm{ccSTP} / \mathrm{g}\right)\end{array}$ & $\begin{array}{c}{ }^{36} \mathrm{Ar} \\
\left(10^{-10} \mathrm{cc} \mathrm{STP} / \mathrm{g}\right)\end{array}$ & $\begin{array}{c}\mathrm{T}(\mathrm{Ma}) \\
\text { air } \\
\text { fraction } \\
(\%)\end{array}$ \\
\hline BDM-07 & 2.305 & 81.10 & $4.96 \pm 0.08$ & $5.95 \pm 0.02$ & $0.55 \pm 0.01$ & 78.0 \\
\hline
\end{tabular}

Table 2: K-Ar age for the underlying basalt at Ban Don Mun

\section{References}

Barr, S., MacDonald, A., Haile, N., Reynolds, P., 1976. Paleomagnetism and age of the Lampang basalt (northern Thailand) and age of the underlying cobble tools. J. Geol. Soc. Thailand 2, 1-10.

Bermudez de Castro, J.M., Arsuaga, J.L., Carbonell, E., Rosas, A., Martinez, I., Mosquera, M., 1997. A hominid from the lower Pleistocene of Atapuerca, Spain: possible ancestor to Neandertals and modern humans. Science 276, 1392-1395.

Boëda, E., Hou, Y., 2011. Etude du site de Longgupo-Synthèse. L'Anthropologie 115, 176-196.

Bordes, F., 1968. Le Paleolithique dans le monde. Hachette, Paris.

Boriskovsky, P., 1966. Basic problems of the prehistoric archaeology of Vietnam. Asian Perspective 9, 8389.

Boriskovsky, P., 1971. Ancient Stone Age of South-eastern Asia. Nauka, Leningrad.

Braun, D., Rogers, M., Harris, J., Walker, S., 2008. Landscape-scale variation in hominin tool use: evidence from the developed Oldowan. J. Hum. Evol. 55, 1053-1063.

Carbonell, E., Bermudez de Castro, J.M., Arsuaga, J.L., Diez, J.C., Rosas, A., Cuenca- Bescos, G., Sala, R., Mosquera, M., Rodriguez, X.P., 1995. Lower Pleistocene hominids and artifacts from Atapuerca-TD6 (Spain). Science 269, 826-830.

Carbonell, E., Bermudez de Castro, J.M., Pares, J.M., Perez-Gonzalez, A., Cuenca Bescós, G., Ollé, A., Mosquera, M., Huguet, R., van der Made, J., Rosas, A., Sala, R., Vallverdu, J., García, N., Granger, D.E., Martinón-Torres, M., Rodriguez, X.P., Stock, G.M., Verges, J.M., Allue, E., Burjachs, F., Caceres, I., Canals, A., Benito, A., Díez, C., Lozano, M., Mateos, A., Navazo, M., Rodriguez, J., Rosell, J., Arsuaga, J.L., 2008. The first hominin of Europe. Nature 452, 465-469.

Carbonell, E., Sala Ramos, R., Pedro Rodriguez, X., Mosquera, M., Olle, A., Verges, J., Martinez-Navarro, B., Bermúdez de Castro, J., 2010. Early hominid dispersals: a technological hypothesis for "out of Africa". Quatern. Int. 223-224, 36-44.

Carbonnel, J.-P., 1972. Le Quaternaire cambodgien: Structure et stratigraphie. In: Mémoires de l'ORSTOM, vol. 60.

Chauhan, P., 2011. Some general thoughts on lower Paleolithic technological dispersals: implications for understanding the Movius Line. In: Yi, S. (Ed.), Handaxes in the Imjin Basin. Snupress, Seoul, pp. 83-126.

Corvinus, G., 2004. Homo erectus in East and Southeast Asia, and the questions of the age of the species and its association with stone artifacts, with special

attention to handaxe-like Tools. Quatern. Int. 117, 141-151.

Dauvois, M., 1976. Précis de dessin dynamique et structural des industries lithiques préhistoriques. Périgueux, Fanlac.

Dennell, R., 2009. The Palaeolithic Settlement of Asia. Cambridge World Archaeology. Cambridge University Press.

Derevianko, A., 2008. Bifacial technique in China. Archaeology Ethnology Anthropol. Eurasia 33, 2-32.

Dizon, E., Pawlik, A., 2010. The lower Palaeolithic record in the Philippines. Quatern. Int. 223-224, 444450.

Forestier, H., Simanjuntak, H.T., Driwantoro, D., 2005. Les premiers indices d'un faciès acheuleen a Sumatra Sud. Les Dossiers d'Archeologie. Numéro spécial Asie du Sud-Est 302, 16-18.

Forestier, H., Sophady, H., Zeitoun, V., Mourer, R., 2012. Le Cambodge avant l'Histoire: aux origines de la préhistoire Khmère. In: Lefèvre, V. (Ed.), Orientalismes. De l'archéologie au musée/Brepols Publishers, Turnhout, pp. 193-212.

Gabunia, L., Vekua, A., Lordkipanidze, D., Swisher III, C.C., Ferring, R., Justus, A., Nioradze, M., Tvalchrelidze, M., Anton, S.C., Bosinski, G., 2000. Earliest Pleistocene hominid cranial remains from Dmanisi, Republic of Georgia: taxonomy, geological setting, and age. Science 288, 1019-1025. 
Gaillard, C., 1996. Processing sequences in Indian lower Palaeolithic: examples from Acheulian and Soanian. Bull. Indo-pacific Prehistory Assoc. 14, 57-67.

Gaillard, C., Singh, M., Rishi, K., 2008. Technological analysis of the Acheulian assemblage from Atbarapur in the Siwalik range (Hoshiarpur district, Punjab). Man. Environ. 33, 1-14.

Gaillard, C., Singh, M., Rishi, K., Bhardwaj, V., 2010. Atbarapur (Hoshiarpur district, Punjab), the Acheulian of the Siwalik range within the south Asian context. Comptes Rendus Palevol. 9, 237-243.

Gorman, C., 1970. Excavations at spirit cave, north Thailand: some interim interpretations. Asian Perspect. 13, 79-107.

Gourou, P., 1948. La civilisation du végétal. Indonésie 1, 385-396.

Heider, K., 1960. A pebble-tool complex in Thailand. Asian Perspect. 2, 63-67.

Hess, A., Koch, K., 1975. Geological Map of Northern Thailand. 1:25,000 Sheet 1 (Nan). Federal Institute for Geosciences and Natural resources. Geo Center, Stuttgart.

Hou, Y., Potts, R., Baoyin, Y., Zhengtang, G., Deino, A., Wei, W., Clark, J., Xie, G., Huang, W., 2000. Mid-pleistocene Acheulean-like stone technology of the Bose basin, south China. Science 28, 1626-1633.

Hou, Y., Zhao, L.X., 2010. An archeological view for the presence of early humans in China. Quatern. Int. 223-224, 10-19.

Huamei, L., Xiaoqiang, Y., Heller, F., Haitao, L., 2008. High resolution magnetostratigraphy and deposition cycles in Nihewan Basin (North China) and their significance for stone artifact dating. Quatern. Res. 69, 250-262.

Huang, W., Ciochon, R., Yumin, G., Larick, R., Qiren, F., Schwarcz, H., Yonge, C., de Vos, J., Rink, W., 1995. Early Homo and associated artefacts from Asia. Nature 378, 275-278.

Hutterer, K., 1977. Reinterpreting the Southeast Asian Palaeolithic. In: Allen, J., Golson, J., Jones, R. (Eds.), Sunda and Sahul: Prehistoric Studies in Southeast Asia, Melanesia and Australia. Academic Press, London, pp. 31-71.

Huy Thong, P., 1976. Our stone Age: from the Mount do industry to the Hoa-binh industry. Vietnamese Stud. 46, 50-106.

Inizan, M.-L., Reduron, M., Roche, H., Tixier, J., 1999. Technology and Terminology of Knapped Stone. C.R.E.P, Meudon.

Keates, S., 2001. The lower palaeolithic of Thailand e the evidence from Lampang. In: Sémah, F., Falgueres, C., Grimaud-Herve, D., Sémah, A.M. (Eds.), Origines des peuplements et chronologie des cultures paléolithiques dans le Sud-Est asiatique. Semenanjung, Paris, pp. 149-165.

Keates, S., 2002. The Movius line: fact or fiction? Indo-pacific Prehistory Assoc. Bull. 22, 17-24.

Larick, R., Ciochon, R., Zaim, Y., Sudijono, Suminto, Rizal, Y., Aziz, F., Reagan, M., Heizler, M., 2001. Early Pleistocene 40Ar/39Ar ages for Bapang Formation hominins, central Java, Indonesia. Proc. Natl. Acad. Sci. 98, 4866-4871.

Lycett, S., Norton, C.J., 2010. A demographic model for Palaeolithic technological evolution: the case of East Asia and the Movius Line. Quatern. Int. 211, 55-65.

MacDonald, S., MacDonald, D.A., 1976. Age of the Lampang Basalt and Underlying Pebble Tools 2. Department of Geological Sciences, Chiang Mai, pp. 1-9. Special publication humans in northeast Asia. Nature. 413, 413-417

Mishra, S., 1992. The age of the Acheulian in India: new evidence. Curr. Anthropol. 33, 325-328.

Mishra, S., 1994. The South Asian lower Palaeolithic. Man. Environ. 19, 57-71.

Morwood, M., O'Sullivan, P., Aziz, F., Raza, A., 1998. Fission-track ages of stone tools and fossils on the east Indonesian island of Flores. Nature 392, 173-176.

Movius, H., 1943. The stone age of Burma. Trans. Am. Philosophical Soc. (New Series) 32, 341-393.

Movius, H., 1944. Early Man and Pleistocene Stratigraphy in Southern and Eastern Asia. In: Papers of the Peabody Museum of American Archaeology and Ethnology, vol. 19. Harvard University, Cambridge.

Movius, H., 1948. The lower Palaeolithic cultures of southern and eastern Asia. Trans. Am. Philosophical Soc. (New Series) 38, 329-420.

Nagao, K., Ogata, A., Miura, Y., Yamaguchi, K., 1996. Ar isotope analysis for KeAr dating using two modified e VG5400 mass spectrometers e I: Isotope dilution method. J. Mass Spectrom. Soc. Jpn. 44, 3661.

Norton, C., Bae, K., 2008. The Movius Line sensu lato (Norton et al., 2006) further assessed and defined. J. Hum. Evol. 55, 1148-1150.

Norton, C., Bae, K., Harris, J., Lee, H., 2006. Middle Pleistocene handaxes from the Korean Peninsula. J. Hum. Evol. 51, 527-536. 
Pappu, S., Gunnell, Y., Akhilesh, K., Braucher, R., Taieb, M., Demory, F., Thouveny, N., 2011. Early Pleistocene presence of Acheulian hominins in South India. Science 331, 1596-1599.

Petraglia, M.D., Shipton, C., 2008. Large cutting tool variation west and east of the Movius Line. J. Hum. Evol. 55, 962-966.

Pawlik, A., Ronquillo, P., 2003. The Palaeolithic in the Philippines. Lithic Technol. 28, 79-93.

Pope, G., 1985. Evidence of early Pleistocene hominid activity from Lampang, Northern Thailand. Bull. Indo-pacific Prehistory Assoc. 6, 2-9.

Pope, G., Frayer, D., Liangcharoen, M., Kulasing, P., Nakabanlang, S., 1981. Paleoanthropological investigations of the Thai American expedition in Northern Thailand (1978e1980): an interim report. Asian Perspect. 21, 147-163.

Pope, G., Barr, S., MacDonald, A., Nakabanlang, S., 1986. Earliest radiometrically dated artifacts from Southeast Asia. Curr. Anthropol. 27, 275-279.

Qiu, Z., 1985. The middle Paleolithic of China. In: Wu, R.K., Olsen, J.W. (Eds.), Palaeoanthropology and Paleolithic Archaeology in the People's Republic of China. Academic Press, New York, pp. 187-210.

Rendell, H., Dennell, R., Halim, M., 1989. Pleistocene and Palaeolithic Investigations in the Soan Valley, northern Pakistan. In: B.A.R International Series, $\mathrm{n}^{\circ} 544$.

Rendell, H., Dennell, R., 1985. Dated lower Palaeolithic artefacts from northern Pakistan. Curr. Anthropol. 26, 393.

Rightmire, P., Lordkipanidze, D., Vekua, A., 2006. Anatomical descriptions, comparative studies and evolutionary significance of the homin skulls from Dmanisi, Republic of Georgia. J. Hum. Evol. 54, 904908.

Sarasin, P., 1933. Prehistorical researches in Siam. J. Siam Soc. 26, 171-202.

Sasada, M., Ratanasthien, B., Soponpongpiat, P., 1987. New KeAr ages from the Lampang basalt, northern Thailand. Bull. Geol. Surv. Jpn. 38, 13-20.

Saurin, E., 1963a. Premiers éléments sur la présence de galets aménagés et de vieux Paléolithique au Cambodge. In: Comptes Rendus Sommaires de la Société de Géologie France, 8, pp. 259-260.

Saurin, E., 1963b. Station préhistorique à Hang Gon près Xuan Loc (Sud Vietnam). Bull. de l'Ecole Française d'Extrême-Orient 2, 443-452.

Saurin, E., 1966. Le Paléolithique du Cambodge oriental. Asian Perspect. 9, 96-110.

Saurin, E., 1971. Le Paléolithique des environs de Xuan Loc. Bull. de la Société d'Etudes Indochinoises 46, 52-67.

Saurin, E., Carbonnel, J.-P., 1964. Les latérites sédimentaires du Cambodge oriental. Revue de Géographie Géologie. dynamique 6, 241-256.

Sémah, F., Sémah, A.M., Djubantono, T., Simanjunak, T., 1992. Did they also make stone tools? J. Hum. Evol. 23, 439-446.

Sémah, F., Saleki, H., Falguères, C., Féraud, G., Djubiantono, T., 2000. Did early man reach Java during the late Pleistocene? J. Archaeological Sci. 27, 763-769.

Sémah, F., 2001. La position stratigraphique de Ngebung 2 (Dôme de Sangiran, Java Central, Indonésie). In: Sémah, F., Falguères, C., Grimaud-Hervé, D., Sémah, A.-M. (Eds.), Origine des peuplements et chronologie des cultures paléolithiques dans le Sud-Est Asiatique. Semenanjung-Artcom, Paris, pp. 299330.

Simanjuntak, H.-T., Forestier, H., 2008. Hand-axe in Indonesia. A question on the Movius line. Hum. Evol. 23, 97-107.

Simanjuntak, H.-T., Sémah, F., Gaillard, C., 2010. The Palaeolithic in Indonesia: nature and chronology. Quatern. Int. 223-224, 418-421.

Solheim,W., 1972. The "new look" of Southeast Asian prehistory. J. Siam Soc. 60, 1-20.

Sondaar, P., Van den Bergh, G., Mubroto, B., Aziz, F., De Vos, J., Batu, U., 1994. Middle Pleistocene faunal turnover and colonization of Flores (Indonesia). C. R. Acad. Sci. Paris 319, 1255-1262.

Sorensen, P., 1976. Preliminary note on the relative and absolute chronology of two early Palaeolithic sites from north Thailand. In: Ghosh, A.K. (Ed.), Le Paleolithique inferieur et moyen en Inde, en Chine et dans le Sud-est asiatique, Union internationale des Sciences Préhistoriques et Protohistoriques, IXth congress, Nice, pp. 237-251.

Sorensen, P., 1981. Further notes on the early Palaeolithic of northern Thailand. A. Newsl. Scand. Inst. Asian Stud. 15, 26-30.

Sorensen, P., 2001. A reconsideration of the chronology of the early Palaeolithic Lannatian culture of north Thailand. Bull. Indo Pac. Prehistory Assoc. 5, 138-141. 
Soriano, S., 2003. Quand archaique n'est pas ancien! Etude de cas dans le Paléolithique du pays Dogon (Ounjougou, Mali). Ann. de la Fondation Fyssen 18, 79-92.

Teilhard de Chardin, P., 1950. Le Paléolithique du Siam. L’Anthropologie 54, 547-549.

Van den Bergh, G., Mubroto, B., Aziz, F., Sondaar, P., De Vos, J., 1996. Did Homo erectus reach the Island of Flores? Indo-pacific Prehistory Assoc. Bull. 14, 27-36.

Van Heekeren, H., 1947. Prehistoric discoveries in Siam 1943-1944. Proc. Prehist.

Soc. 14, 24-32.

Van Heekeren, H., 1972. The Stone Age of Indonesia. Nijhoff, The Hague.

Van Tan, H., 1980. Nouvelles recherches préhistoriques et protohistoriques au Viêtnam. Bull. de l'Ecole Française d'Extrême Orient 68, 54-113.

Vekua, A., 1995. Die Wirbeltierfauna des Villafranchium von Dmanisi und ihre biostratigraphische Bedeutung. In: Jahrbuch der Romischen-German Zentralmuseums Mainz, vol. 42, pp. 77-180.

Vekua, A., Lordkipanidze, D., Rightmire, G.P., Agustí, J., Ferring, R., Maisuradze, G., Mouskhelishvili, A., Nioradze, M., Ponce de León, M., Tappen, M., Tvalchreridze, M., Zollikofer, C., 2002. A new skull of early Homo from Dmanisi, Georgia. Science 297, 85-89.

Voris, H., 2000. Maps of Pleistocene sea levels in southeast Asia: shorelines, river systems and time durations. J. Biogeogr. 27, 1153-1161.

Wang, S., 2006. Cleavers collected from the open-air sites in Luonan Basin, China. Acta Anthropol. Sinica $25,332-342$.

Westergaard, G., Suomi, S., 1995. The manufacture and use of bamboo tools by monkeys: possible implications for the development of material culture among East Asian hominids. J. Archaeological Sci. 22, 677-681.

Yi, S., 2011. Handaxes in the Imjin basin. In: Yi, S. (Ed.), Handaxes in the Imjin Basin. Snupress, Seoul, pp. 3-21.

Yi, S., Clark, G.A., 1983. Observations on the lower Palaeolithic of northeast Asia. Curr. Anthropol. 24, $181-202$.

Zeitoun, V., Détroit, F., Grimaud-Hervé, D., Widianto, H., 2010. Solo man in question: convergent views to split Indonesian Homo erectus in two categories. Quatern. Int. 223-224, 281-292.

Zeitoun, V., Forestier, H., Auetrakulvit, P., Khaokhiew, C., Rasse, M., Davtian, G., Winayalai, C., Tiamtinkrit, C., 2012. Discovery of a prehistoric site at Sao Din (Nanoi, Nan province, Northern Thailand): stone tools and new geological insights. C. R. Palevol 11, 575-580.

Zhu, R., An, Z., Potts, R., Hoffman, K., 2003. Magnetostratigraphic dating of early humans in China. Earth Sci. Rev. 61, 341-359.

Zhu, R., Hoffman, K., Potts, R., Deng, C., Pan, Y., Guo, B., Shi, C., Guo, Z., Yuan, B., Hou, Y., Huang, W., 2001. Earliest presence of humans in northeast Asia. Nature 413, 413-417. 